\title{
Silent hepatitis E virus infection in Dutch blood donors, 2011 to 2012
}

E Slot ${ }^{1,2}$, B M Hogema ${ }^{1,2}$, A Riezebos-Brilman³, T M Kok' ${ }^{1}$ M Molier ${ }^{1}$, H L Zaaijer (h.zaaijer@sanquin.nl) ${ }^{1,4}$

1. Department of Blood-borne Infections, Sanquin Blood Supply Foundation, Amsterdam, the Netherlands

2. These authors contributed equally to this study

3. Department of Medical Microbiology, University Medical Center Groningen, Groningen, the Netherlands

4. Department of Clinical Virology (CINIMA), Academic Medical Center, Amsterdam, the Netherlands

Slot E, Hogema BM, Riezebos-Brilman A, Kok TM, Molier M, Zaaijer HL. Silent hepatitis E virus infection in Dutch blood donors, 2011 to 2012 . Euro Surveill.

2013;18(31): pii=20550. Available online: http://www.eurosurveillance.org/ViewArticle.aspx?Articleld=20550

In Europe, the dynamics of endemic hepatitis $\mathrm{E}$ virus (HEV) infection remain enigmatic. We studied the presence of silent HEV infection among Dutch blood donors. Using donations collected throughout the Netherlands in 2011 and 2012, 40,176 donations were tested for HEV RNA in 459 pools of 48 or 480 donations. Deconstruction of the reactive pools identified 13 viraemic donors. In addition, 5,239 donors were tested for presence of anti-HEV IgG and IgM and for HEV RNA when IgM-positive. Of the 5,239 donations, 1,401 (27\%) tested repeat-positive for HEV IgG, of which 49 (3.5\%) also tested positive for antiHEV IgM. Four of the HEV IgM-positive donors tested positive for HEV RNA. HEV IgG seroprevalence ranged from $13 \%$ among donors younger than 30 years to $43 \%$ in donors older than 60 years. The finding of 17 HEV RNA-positive donations among 45,415 donations corresponds to one HEV-positive blood donation per day in the Netherlands. For 16 of the $17 \mathrm{HEV}$ RNA-positive donors, genotyping succeeded, revealing HEV genotype 3, which is circulating among Dutch pigs. Apparently, silent HEV infection is common in the Netherlands, which possibly applies to larger parts of Europe.

\section{Introduction}

Hepatitis E virus (HEV) is a non-enveloped RNA virus, classified into four genotypes. HEV genotypes 1 and 2 have been found only in humans, whereas genotypes 3 and 4 have also been found in animals. The clinical features of hepatitis $E$ are similar to those of viral hepatitis caused by other hepatotropic viruses. In Europe and North America, hepatitis E is known as an acute disease in travellers returning from tropical countries, but an endemic source of hepatitis $E$ has always been suspected [1]. Recently it became clear that genotype 3 of hepatitis E virus (HEV gt-3) is widely spread among pigs in Europe, North America and Japan [2,3]. Surprisingly, infection of humans by HEV gt-3 seems to cause disease mainly in immunosuppressed persons, such as patients who have received organ transplants $[4,5]$, who may develop chronic hepatitis $E[6,7]$. Blood donors can be silently infected with HEV, as indicated by plasma pools testing positive for HEV RNA $[8,9]$ and by a high prevalence of antibodies to HEV among blood donors in the south west of France [10]. Cases of transfusion-transmitted hepatitis $E$ have been reported [11-14]. The dynamics of HEV gt-3 infection and its implications for public health and the safety of blood are largely unknown. Which part of the population has signs of resolved or active infection? To estimate the infection pressure of HEV in the Netherlands, we determined the presence of HEV RNA and HEV antibodies in a large number of recent blood donations, collected throughout the country.

\section{Methods}

\section{Collection and selection of samples}

To estimate the presence of HEV in the donor population, 417 plasma pools of 48 blood donations each (representing 20,016 donations, collected from November 2011 through January 2012); and 42 plasma pools of 480 donations each (representing 20,160 donations, collected in April and May 2012) were tested for presence of HEV RNA. All Dutch blood collection centres participated, thus all regions of the Netherlands were represented. The switch to pools of 480 was made after performing PCR on the 417 pools of 48 donations, as it appeared that the level of viraemia in recent HEV infection was sufficient to be detected in pools of 480 . Plasma pools testing positive for HEV RNA were deconstructed to identify and genotype individual HEV RNApositive donations.

In addition, plasma samples from 5,239 consenting blood donors were collected on two days in March 2011 to determine HEV IgG seroprevalence, with subsequent testing for HEV IgM and HEV RNA in IgG-positive donations. All Dutch collection centres participated, thus all regions of the Netherlands were represented. Finally, for 391 donors testing positive for HEV IgG, archived samples of blood donations collected in 2009 were 


\begin{tabular}{|c|c|c|c|c|c|c|c|c|c|}
\hline \multicolumn{3}{|c|}{ Donor } & \multicolumn{4}{|c|}{ Test results of index donation } & \multicolumn{3}{|c|}{ Findings in serial donations } \\
\hline \multirow[b]{2}{*}{ Donor } & \multirow[b]{2}{*}{$\begin{array}{l}\text { Sex and } \\
\text { age (years) }\end{array}$} & \multirow[b]{2}{*}{$\begin{array}{c}\text { Urbani- } \\
\text { sation }\end{array}$} & \multicolumn{2}{|c|}{ Anti-HEV } & \multirow[b]{2}{*}{$\begin{array}{c}\text { HEV-RNA } \\
\text { (IU/mL) }\end{array}$} & \multirow[b]{2}{*}{$\begin{array}{c}\text { HEV } \\
\text { genotype }\end{array}$} & \multirow[b]{2}{*}{$\begin{array}{l}\text { Anti-HEV } \\
\text { sero- } \\
\text { conversion }\end{array}$} & \multicolumn{2}{|c|}{ Interval in days between } \\
\hline & & & $\lg G$ & $\lg M$ & & & & $\begin{array}{c}\text { first and } \\
\text { last HEV } \\
\text { RNA- } \\
\text { positive } \\
\text { donation }\end{array}$ & $\begin{array}{c}\text { last and } \\
\text { first HEV } \\
\text { RNA- } \\
\text { negative } \\
\text { donation }\end{array}$ \\
\hline 1 & M 36 & 3 & + & - & $5.2 \times 10^{3}$ & 3 & Yes & NA & NA \\
\hline 2 & M 26 & 5 & ++ & ++ & $5.1 \times 10^{2}$ & 3 & Yes & 58 & NA \\
\hline 3 & M 54 & 4 & - & - & $4.7 \times 10^{5}$ & 3 & NA & NA & NA \\
\hline 4 & $\mathrm{~F} 25$ & 1 & - & - & $4.9 \times 10^{2}$ & 3 & Yes & NA & NA \\
\hline 5 & M 63 & 4 & - & - & $2.8 \times 10^{3}$ & 3 & Yes & NA & 70 \\
\hline 6 & M 50 & 3 & - & - & $9.8 \times 10^{2}$ & 3 & NA & NA & NA \\
\hline 7 & $M_{58}$ & 2 & + & + & $6.8 \times 10^{2}$ & 3 & Yes & 56 & 84 \\
\hline 8 & $\mathrm{~F}_{51}$ & 3 & - & - & $2.7 \times 10^{5}$ & 3 & NA & NA & NA \\
\hline 9 & F 44 & 4 & + & - & $1.8 \times 10^{2}$ & NA & NA & NA & NA \\
\hline 10 & M 69 & 3 & - & - & $3.5 \times 10^{4}$ & 3 & Yes & 56 & 115 \\
\hline 11 & F 57 & 3 & - & - & $3.0 \times 10^{4}$ & 3 & NA & NA & NA \\
\hline 12 & M 65 & 5 & - & - & $1.4 \times 10^{4}$ & 3 & Yes & 27 & 91 \\
\hline 13 & M 41 & 3 & - & - & $2.2 \times 10^{3}$ & 3 & Yes & NA & 63 \\
\hline 14 & M 67 & 2 & +++ & +++ & $3.7 \times 10^{4}$ & 3 & Yes & NA & 201 \\
\hline 15 & M 64 & 2 & +++ & + & Pos<25 & 3 & Yes & 35 & 105 \\
\hline 16 & M 60 & 2 & ++ & + & $4.5 \times 10^{2}$ & 3 & Yes & 43 & 86 \\
\hline 17 & M 57 & 4 & +++ & + & Pos $<25$ & 3 & Yes & 42 & 83 \\
\hline
\end{tabular}

F: female; HEV: hepatitis E virus; M: male; NA: no sample available; -: negative; + to +++: positive.

Donors 1-13: detected by PCR testing of 40,176 donations. Donors 14-17: detected by serological testing of 5,239 donations.

The level of urbanisation ranges from $1=$ highly urbanised $\left(\geq 2500\right.$ addresses $\left./ \mathrm{km}^{2}\right)$ to $5=\mathrm{rural}\left(\left(500\right.\right.$ addresses $\left./ \mathrm{km}{ }^{2}\right)$. IgG and IgM anti-HEV signals are categorised according to measured sample-to-cut-off (S/CO) ratios, as follows:

$\mathrm{S} / \mathrm{CO}<1.0=-; 1.0 \leq \mathrm{S} / \mathrm{CO}<5.0=+; 5.0 \leq \mathrm{S} / \mathrm{CO}<10.0=++; \mathrm{S} / \mathrm{CO} \geq 10.0=+++$.

retrieved for retrospective testing, to estimate the incidence of HEV infection in previous years.

Detection and genotyping of

hepatitis E virus RNA

Amplification of a 74 bp fragment of HEV $\mathrm{ORF}_{3}$ was adapted from Pas et al. [7]. RNA was extracted from $0.4 \mathrm{~mL}$ of plasma using the QIAamp MinElute Virus Spin Kit (QIAGEN) on a nucleic acid extractor (QIAcube, QIAGEN) and eluted in $50 \mu \mathrm{L}$ according to the manufacturer's protocol. For repository samples, $60 \mu \mathrm{l}$ of plasma was diluted into $400 \mu \mathrm{l}$ before extraction. MS2 phage was added prior to extraction as an internal control. Amplification used $20 \mu \mathrm{L}$ of eluate in a $50 \mu \mathrm{L}$ volume containing $12.5 \mu \mathrm{L}$ of TaqMan Fast Virus 1-Step Master Mix (Applied Biosystems), $0.2 \mu \mathrm{M}$ HEV probe (FAM-ATTCTCAGCCCTTCGC-MGB, Applied Biosystems), and $0.6 \mu \mathrm{M}$ of HEV forward primer (CGGTGGTTTCTGGGGTGA, Invitrogen) and $0.9 \mu \mathrm{M}$ HEV reverse primer (GCRAAGGGRTTGGTTGG, Invitrogen). PCR was performed using a real-time $P C R$ system (LightCycler 480-II, Roche) and standard PCR conditions. Reactions were performed in duplicate, with and without MS2 detection using MS2-specific primers and a Hex/BHQ1 labelled Taqman probe [15]. The lower limit of detection ( $95 \%$ cut-off) of the assay is ca. $25 \mathrm{IU} / \mathrm{mL}$ HEV RNA. HEV viral loads were calculated retrospectively from the PCR Ct values, using a calibration curve based on the first World Health Organization (WHO) International Standard for HEV RNA [16], which later became available. HEV genotyping was performed by amplification and sequencing of a $326 \mathrm{bp}$ fragment of the ORF2 region [17] using AMV RT and GoTaq DNA polymerase (Promega) according to the manufacturer's instructions. If the HEV-RNA load in the index donation was too low, genotyping was performed using earlier or later samples of the donor. Sequence analysis was performed using DNAstar and Geneious software, using HEV reference sequences as described by Baylis et al. [18] and additional HEV sequences from GenBank. Genetic distances were calculated using the Tamura-Nei model, the phylogenetic tree was constructed using the neighbour-joining method. The 16 blood donor HEV sequences obtained in this study are 
available in GenBank via accession codes JX645320JX645333, JX678984 and KC223601. For comparison, HEV sequences from seven Dutch endemic hepatitis E patients were included, diagnosed in 2011 or 2012 in our laboratory. No further patient information was available. The seven patient HEV sequences are available via GenBank accession codes JX645334-JX645340.

\section{Serological testing}

Samples were screened for IgG antibodies to HEV using an anti-HEV IgG enzyme immuno assay (EIA) (Wantai Biological Pharmacy Enterprise Co., Ltd., Beijing, China) $[5,10,19,20]$. Positive samples were tested for presence of anti-HEV IgM antibodies by an anti-HEV IgM EIA (Wantai). Positive samples were considered anti-HEV positive if found positive upon repeated testing. The assays were performed following the manufacturer's instructions. IgM-positive samples were tested for presence of HEV RNA and, if PCR-positive, were subsequently genotyped. Archived serial samples from HEV RNA-positive donors were tested to confirm seroconversion and to determine the duration of viraemia.

\section{Statistical analysis and}

\section{geographical information}

The chi-square test was used for statistical analysis. The Newcombe-Wilson method was applied to determine $95 \%$ confidence intervals $(\mathrm{Cls})$. The age-seroprevalence curve was calculated using a second-degree polynomial fit. For incidence calculation, seroconversion was defined as conversion from seronegative to seropositive in subsequent donations, together with at least a threefold increase of the HEV IgG sample-tocut-off EIA value. The degree of urbanisation for postal code areas was provided by the central bureau for statistics (CBS), using a five-point scale ranging from 1 (highly urbanised, $\geq 2,500$ addresses $/ \mathrm{km}^{2}$ ) to 5 (rural, $<500$ addresses $/ \mathrm{km}^{2}$ ).

\section{Results}

The screening of 459 plasma pools, containing 40,176 blood donations, for presence of HEV RNA, resulted in the identification of $13 \mathrm{HEV}$ viraemic donors (Donors 1 to 13 in Table 1, red flags in Figure 1). If possible, the presence of HEV infection was confirmed by detection of HEV RNA in the original plasma bag. Seven donors were detected among the 20,016 donations in pools of 48 , six donors among the 20,160 donations in pools of 480 . Nine of the 13 donors were in the early, seronegative phase of infection. For five of these seronegative donors a follow-up sample was available, and for three seropositive donors an earlier sample was available; all demonstrating seroconversion and confirming recent infection. An indication of the duration of viraemia was obtained as follows: In seven donors HEV was detectable in serial donations, 27 to 58 days apart (see 'first to last HEV RNA-positive donation' in Table 1). In nine donors, an HEV-negative donation was available before and after the viraemic donation, 83 to 201 days
FIGURE 1

Hepatitis E virus-infected blood donors in the Netherlands, 2011-2012 ( $\mathrm{n}=17)$

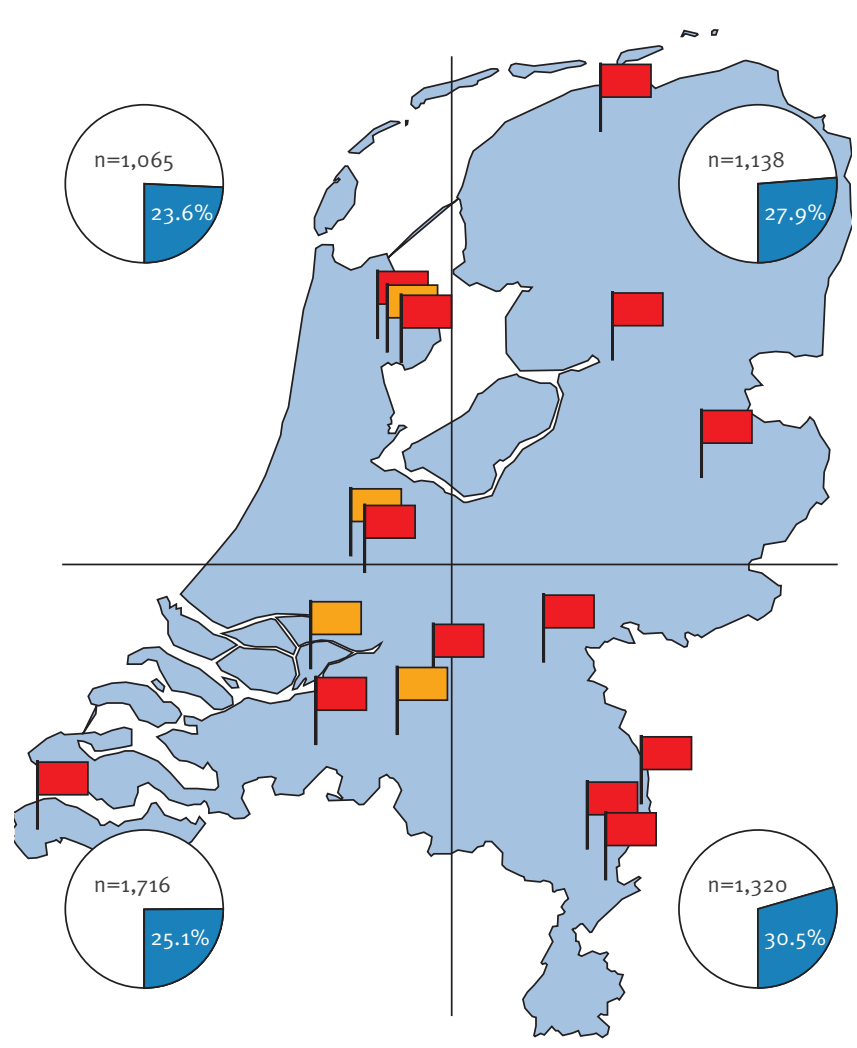

Flags indicate the residence of HEV RNA-positive donors (red: detected via PCR on plasma pools; orange: detected via serology). Pie diagrams show the IgG anti-HEV seroprevalence in the four quadrants of the country.

apart (see 'last to first HEV RNA-negative donation in Table 1).

Screening of 5,239 donors for the presence of HEV antibodies revealed 1,401 donors who were repeat-reactive for anti-HEV IgG, resulting in a seroprevalence of $26.7 \%$ (95\% Cl: 25.6-28.0). Some regional variation was observed (Table 2 and Figure 1): the seroprevalence in the south-eastern part of the Netherlands (30.5\%) was higher than in the rest of the country $(p=0.0004)$, while the seroprevalence in the north-western part was lower $(23.6 \%, p=0.009)$. Anti-HEV IgG seroprevalence strongly increased with age: after the age of 30 years, the seroprevalence increased linearly with $1.05 \%$ per year (Figure 2; $\mathrm{R}^{2}=0.98$ ). The variation in seroprevalence in different parts of the Netherlands cannot be not explained by different age distributions of local donor populations. The overall seroprevalence in males was higher than in females (29.2 versus $23.1 \%$ ), but this difference can be attributed to the higher average age of male donors (51.1 versus 45.5 years); no difference was observed when age-weighed seroprevalences were compared. 
TABLE 2

Anti-hepatitis E virus IgG seroprevalence among blood donors, the Netherlands, 2011-2012 ( $\mathrm{n}=5,239)$

\begin{tabular}{|c|c|c|c|c|}
\hline & \multicolumn{2}{|c|}{ Anti-HEV IgG status } & \multicolumn{2}{|c|}{ Average age (years) } \\
\hline & Positive/tested & Seroprevalence & IgG-positive & IgG-negative \\
\hline Total & $1,401 / 5,239$ & $26.7 \%$ & 54.1 & 46.9 \\
\hline Male & $911 / 3,119$ & $29.2 \%$ & 55.6 & 49.3 \\
\hline Female & $490 / 2120$ & $23.1 \%$ & 51.2 & 43.8 \\
\hline \multicolumn{5}{|l|}{ Region } \\
\hline North-east & $317 / 1,138$ & $27.9 \%$ & 53.3 & 47.9 \\
\hline South-east & $402 / 1,320$ & $30.5 \%$ & 54.0 & $47 \cdot 3$ \\
\hline North-west & $251 / 1,065$ & $23.6 \%$ & 54.7 & 45.8 \\
\hline South-west & $431 / 1,716$ & $25.1 \%$ & 54.2 & 46.7 \\
\hline \multicolumn{5}{|c|}{ Level of urbanisation ${ }^{a}$} \\
\hline 1 & $196 / 827$ & $23.7 \%$ & 52.3 & 42.3 \\
\hline 2 & $384 / 1,366$ & $28.1 \%$ & 54.8 & 47.0 \\
\hline 3 & $263 / 995$ & $26.4 \%$ & 53.7 & 47.4 \\
\hline 4 & $273 / 1,054$ & $25.9 \%$ & 54.6 & 47.7 \\
\hline 5 & $263 / 916$ & $28.7 \%$ & 54.4 & 49.6 \\
\hline
\end{tabular}

HEV: hepatitis E virus.

a The level of urbanisation ranges from $1=$ highly urbanised $\left(\geq 2,500\right.$ addresses $\left./ \mathrm{km}^{2}\right)$ to $5=$ rural $\left(<500\right.$ addresses $\left./ \mathrm{km}^{2}\right)$. For $81 \mathrm{donors,} \mathrm{no}$ information on the urbanisation level was available.

The anti-HEV IgG seroprevalence did not correlate with the level of urbanisation (Table 2). The lower seroprevalence in highly urban areas can be explained by the lower average age of urban donors. The HEV seroprevalence in the area with the highest density of pigs (surrounding the city of Eindhoven), was not different from the seroprevalence of the rest of the south-eastern part of the Netherlands (30.2\% versus $30.6 \%$ ).

The incidence of HEV infection in recent years was estimated by measuring anti-HEV IgG in earlier, archived samples collected in 2009 from the 391 donors who tested positive for anti-HEV IgG in 2011. The total time span, covered by the serial samples, was 571 years. Seventeen donors seroconverted during this period, indicating an incidence of $1.1 \%$ per person-year $(95 \%$ $\mathrm{Cl}: 0.65-1.7)$.

Forty-nine (3.5\%) of the 1,401 anti-HEV IgG positive donors tested positive for IgM anti-HEV. Four of these IgM-positive donors tested positive for HEV RNA (Donors 14 to 17 in Table 1, and orange flags in Figure 1). Serial samples of all four donors showed IgM and IgG anti-HEV seroconversion, confirming recent infection.

HEV viral loads in the 17 viraemic donors ranged from near the detection limit ( $\$ 25 \mathrm{IU} / \mathrm{mL}$ HEV RNA) to more than $100,000 \mathrm{IU} / \mathrm{mL}$ HEV RNA. In seven donors HEV viraemia occurred in up to five serial donations, with a maximum recorded viraemic period of 58 days (Donor 2 in Table 1). In 16 of the 17 viraemic donors HEV genotyping succeeded, showing the presence of HEV genotype
3. Phylogenetic analysis of the HEV sequences suggested clustering with each other, with Dutch endemic hepatitis E patients and with HEV sequences obtained from Dutch pigs, see Figure 3.

\section{Discussion}

The detection of HEV viraemia in 17 of 45,415 recent Dutch blood donations demonstrates a high incidence of HEV infection in the Netherlands. Our serological screening suggested that roughly one quarter of the Dutch adult population experienced HEV infection. This proportion compares with the $16 \%$ of 500 donors in the south-west of Britain [19], and the $53 \%$ of 512 donors in the south-west of France [10], who recently tested positive for IgG anti-HEV, using the same antibody assay as employed in this study. Unfortunately, there is no gold standard for $\mathrm{HEV}$ antibody testing. A recent study reports an HEV IgG seroprevalence of only $2.6 \%$ in 7,072 Dutch samples, collected in 2006 and 2007, employing another brand of HEV antibody assay (MP/ Genelabs) [21]. The Wantai assay used in the present study may suffer from a high level of non-specific reactivity. However, studies comparing the performance of the Wantai and the MP/Genelabs assay demonstrate a higher sensitivity and detection of more sera from PCRproven cases by the Wantai assay $[10,20]$. Classical anti-HEV serology probably lacks sensitivity and seems unsuitable to confirm Wantai EIA test results. In addition, the frequent finding of HEV RNA-positive donors (Table 1), the striking age-related increase of HEV IgG seroprevalence (Figure 2), and the fact that already in 2005, HEV was found to circulate on 53 of 97 Dutch 
FIGURE 2

Anti-hepatitis $\mathrm{E}$ virus IgG seroprevalence in 10-year age groups of blood donors, the Netherlands, 2011-2012 $(\mathrm{n}=5,239)$

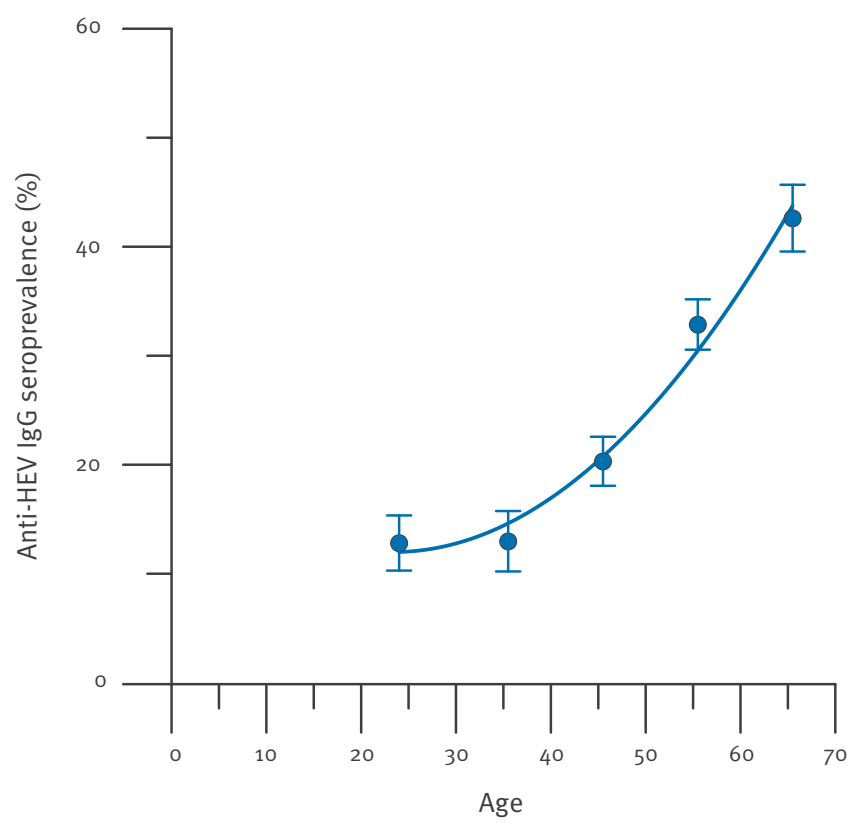

The first group represents donors between 18 and 29 years rather than a 10 -year group. Error bars indicate the $95 \%$ confidence interval for each age group.

pig farms [2], suggest that the high seroprevalence as detected by the Wantai assay may be correct.

Unfortunately, seroprevalence data for persons under the age of 18 are not available. The striking age-related seroprevalence (Figure 2) is difficult to interpret. The age-dependent seroprevalence may simply reflect a long-standing, stable situation, in which people are evenly exposed to HEV in the course of their life. In that scenario, the current high number of viraemic and seroconverting donors may reflect a temporary elevation of $\mathrm{HEV}$ infection pressure. If endemic HEV infection were a recent phenomenon, the age-dependent seroprevalence could only be explained by age-dependent exposure or age-dependent susceptibility, which is difficult to imagine for a food-borne pathogen. Alternatively, the seroprevalence curve could reflect an age-cohort effect, caused by transient exposure of older generations in the past. Such a cohort effect has been described in England [22]. The HEV incidence found in this study of $1 \%$ per year, as well as the high number of HEV RNA-positive blood donors, seem to contradict transient exposure to HEV in the past; but endemic HEV may have returned after a long period of absence.

HEV transmission by blood transfusion has been reported in Saudi Arabia, Japan, France and the United Kingdom [11-14]. Our results suggest roughly one HEV viraemic donation per day in the Netherlands. This may be an underestimation, considering that the serological screening of 5,239 donors only detected antibodypositive donors in a later stage of infection (Donors 14 to 17 in Table 1), while the screening for HEV RNA of 40,176 pooled (diluted) donations detected donors in an early stage of infection, with high levels of HEV RNA and low or absent HEV antibodies (Donors 1 to 13). HEV RNA-positive blood may pose a threat to immunosuppressed blood recipients, such as recipients of organ transplants and patients with haematological malignancies; and possibly to pregnant women [23]. Because blood transfusion is only a minor source of $\mathrm{HEV}$ infection, the routine screening of blood donations for the presence of HEV does not yet seem warranted. Each immunosuppressed patient with unexplained elevated liver enzymes should be tested for the presence of HEV RNA, irrespective of exposure to blood products. Fortunately, it appears that chronic HEV infection in immunosuppressed patients can be cured by a temporary reduction of immunosuppression, or by antiviral treatment using ribavirin $[5,24]$.

The source and transmission routes of HEV gt- 3 infection have not yet been uncovered. In contrast to the Midi-Pyrénées region of France, where an association of HEV seropositivity with rural residence was found [10], the level of urbanisation and the vicinity of pig farms do not play a role in the Netherlands. Until recently, little was known of HEV transmission dynamics in European pig populations. Berto et al. describe the presence of HEV in 8 to $73 \%$ of stool samples collected from pig farms between 2007 and 2011 throughout Europe, and the presence of HEV in fattening pigs [25]. It is unclear whether pigs are the source of the current HEV infections. Intensive pig farming may have become the major amplifier of the virus, considering that millions of pigs are being reared in the Netherlands each year, of which each year again a large part probably acquires and sheds HEV. Subsequently, HEV may be spread via contaminated meat $[26,27]$ or via faecally contaminated water used for irrigation [28]. Studies are needed to identify the transmission routes of HEV gt-3 to humans, so that appropriate measures can be taken. It seems likely that at this moment other Western countries also experience extensive, silent HEV infection. 


\section{FIGURE 3}

Phylogenetic comparison of hepatitis E virus RNA sequences (a 326 bp fragment of ORF2), the Netherlands, 2011-2012 $(\mathrm{n}=30)$

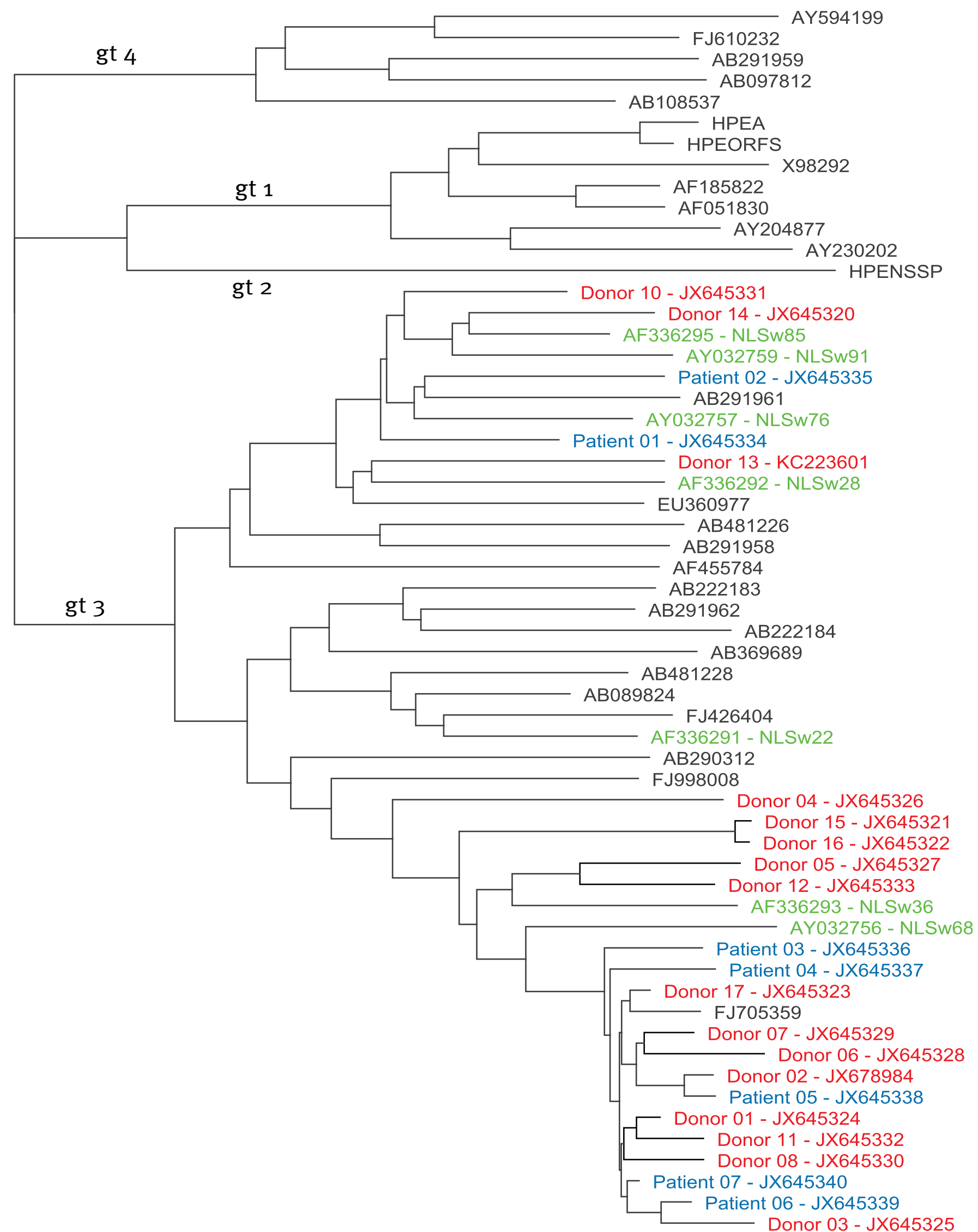




\section{References}

1. Zaaijer HL, Kok M, Lelie PN, Timmerman RJ, Chau K, van der Pal HJ. Hepatitis E in The Netherlands: imported and endemic. Lancet. 1993:341(8848):826.

http://dx.doi.org/10.1016/0140-6736(93)90599-C

2. Rutjes SA, Lodder WJ, Bouwknegt M, de Roda Husman AM Increased hepatitis E virus prevalence on Dutch pig farms from 33 to $55 \%$ by using appropriate internal quality controls for RTPCR. J Virol Methods. 2007:143(1):112-6. http://dx.doi.org/10.1016/j.jviromet.2007.01.030 PMid:17320980

3. Dalton HR, Bendall R, ljaz S, Banks M. Hepatitis E: an emerging infection in developed countries. Lancet Infect Dis. 2008;8(11):698-709. http://dx.doi.org/10.1016/S1473-3099(08)70255-X

4. Kamar N, Selves J, Mansuy JM, Ouezzani L, Péron JM, Guitard J, et al. Hepatitis E virus and chronic hepatitis in organtransplant patients. N Engl J Med. 2008;358(8):811-7. http://dx.doi.org/10.1056/NEJMoa0706992 PMid:18287603

5. Kamar N, Bendall R, Legrand-Abravanel F, Xia NS, ljaz S, Izopet J, et al. Hepatitis E. Lancet. 2012;379(9835):2477-88. http://dx.doi.org/10.1016/S0140-6736(11)61849-7

6. Kamar N, Garrouste C, Haagsma EB, Garrique V, Pischke S, Chauvet $\mathrm{C}$, et al. Factors associated with chronic hepatitis in patients with hepatitis $\mathrm{E}$ virus infection who have received solid organ transplants. Gastroenterology. 2011;140(5):1481-9. http://dx.doi.org/10.1053/j.gastro.2011.02.050 PMid:21354150

7. Pas SD, de Man RA, Mulders C, Balk AH, van Hal PT, Weimar W, et al. Hepatitis $\mathrm{E}$ virus infection among solid organ transplant recipients, the Netherlands. Emerg Infect Dis. 2012;18(5):86972. http://dx.doi.org/10.3201/eid1805.111712 PMid:22516170 PMCid:PMC3358074

8. Baylis SA, Gärtner T, Nick S, Ovemyr J, Blümel J. Occurrence of hepatitis E virus RNA in plasma donations from Sweden, Germany and the United States. Vox Sang. 2012;103(1):89-90. http://dx.doi.org/10.1111/j.1423-0410.2011.01583.x PMid:22220775

9. Ijaz S, Szypulska R, Tettmar KI, Kitchen A, Tedder RS. Detection of hepatitis $E$ virus RNA in plasma mini-pools from blood donors in England. Vox Sang. 2012;102(3):272. http://dx.doi.org/10.1111/j.1423-0410.2011.01554.x PMid:21957873

10. Mansuy JM, Bendall R, Legrand-Abravanel F, Sauné K, Miédouge M, Ellis V, et al. Hepatitis E virus antibodies in blood donors, France. Emerg Infect Dis. 2011;17(12):2309-12. http://dx.doi.org/10.3201/eid1712.110371 PMid:22172156 PMCid:PMC3311200

11. Boxall E, Herborn A, Kochethu G, Pratt G, Adams D, ljaz S, et al. Transfusion-transmitted hepatitis $\mathrm{E}$ in a 'nonhyperendemic' country. Transfus Med. 2006;16(2):79-83. http://dx.doi.org/10.1111/j.1365-3148.2006.00652.x PMid:16623913

12. Colson P, Coze C, Gallian P, Henry M, De Micco P, Tamalet C. Transfusion-associated hepatitis E, France. Emerg Infect Dis. 2007;13(4):648-9.

http://dx.doi.org/10.3201/eid1304.061387 PMid: 17561564 PMCid:PMC 2725983

13. Matsubayashi K, Nagaoka Y, Sakata H, Sato S, Fukai K, Kato T, et al. Transfusion-transmitted hepatitis E caused by apparently indigenous hepatitis E virus strain in Hokkaido, Japan. Transfusion. 2004:44(6):934-40.

http://dx.doi.org/10.1111/j.1537-2995.2004.03300.x PMid:15157263

14. Matsubayashi K, Kang JH, Sakata H, Takahashi K, Shindo M, Kato $M$, et al. A case of transfusion-transmitted hepatitis $E$ caused by blood from a donor infected with hepatitis E virus via zoonotic food-borne route. Transfusion. 2008;48(7):136875 . http://dx.doi.org/10.1111/j.1537-2995.2008.01722.x PMid:18651907

15. Dreier J, Störmer M, Kleesiek K. Use of bacteriophage MS2 as an internal control in viral reverse transcription-PCR assays. Clin Microbiol. 2005;43(9):4551-7. http://dx.doi.org/10.1128/JCM.43.9.4551-4557.2005 PMid:16145106 PMCid:PMC1234060

16. Baylis SA, Blümel J, Mizusawa S, Matsubayashi K, Sakata $\mathrm{H}$, Okada Y, et al. World Health Organization International Standard to Harmonize Assays for Detection of Hepatitis E Virus RNA. Emerg Infect Dis. 2013;19(5):729-35.

http://dx.doi.org/10.3201/eid1905.121845 PMid:23647659 PMCid:PMC3647515

17. Meng XJ, Purcell RH, Halbur PG, Lehman IR, Webb DM, Tsareva TS, et al. A novel virus in swine is closely related to the human hepatitis E virus. Proc Natl Acad Sci. U.S.A. 1997;94(18):9860http://dx.doi.org/10.1073/pnas.94.18.9860 PMid:9275216 PMCid:PMC23282

18. Baylis SA, Hanschmann KM, Blümel J, Nübling CM; HEV Collaborative Study Group. Standardization of hepatitis E virus (HEV) nucleic acid amplification technique-based assays: an initial study to evaluate a panel of HEV strains and investigate laboratory performance. J Clin Microbiol. 2011;49(4):1234-9. http://dx.doi.org/10.1128/JCM.02578-10 PMid:21307208 PMCid:PMC3122834

19. Dalton HR, Stableforth W, Thurairajah P, Hazeldine S, Remnarace R, Usama W, et al. Autochthonous hepatitis E in Southwest England: natural history, complications and seasonal variation, and hepatitis $\mathrm{E}$ virus Ig G seroprevalence in blood donors, the elderly and patients with chronic liver disease. Eur J Gastroenterol Hepatol. 2008;20(8):784-90. http://dx.doi.org/10.1097/MEG.obo13e3282f5195a PMid:18617784

20. Bendall R, Ellis V, ljaz S, Ali R, Dalton H. A comparison of two commercially available anti-HEV IgG kits and a re-evaluation of anti-HEV IgG seroprevalence data in developed countries. I Med Virol. 2010;82(5):799-805.

http://dx.doi.org/10.1002/jmv.21656 PMid:20336757

21. Verhoef L, Koopmans M, Duizer E, Bakker J, Reimerink J, van Pelt W. Seroprevalence of hepatitis E antibodies and risk profile of HEV seropositivity in The Netherlands, 2006-2007. Epidemiol Infect. 2012;140(10):1838-47. http://dx.doi.org/10.1017/S0950268811002913 PMid:22269886

22. Ijaz S, Vyse AJ, Morgan D, Pebody RG, Tedder RS, Brown D. Indigenous hepatitis E virus infection in England: more common than it seems. I Clin Virol. 2009;44(4):272-6. http://dx.doi.org/10.1016/j.jcv.2009.01.005 PMid:19217345

23. Anty R, Ollier L, Péron JM, Nicand E, Cannaro I, Bongain A, et al. First case report of an acute genotype 3 hepatitis E infected pregnant woman living in South-Eastern France. J Clin Virol. 2012;54(1):76-8.

http://dx.doi.org/10.1016/j.jcv.2012.01.016 PMid:22336086

24. Wedemeyer H, Pischke S, Manns MP. Pathogenesis and Treatment of Hepatitis E Virus Infection. Gastroenterology. 2012;142(6):1388-97. http://dx.doi.org/10.1053/j.gastro.2012.02.014 PMid:22537448

25. Berto A, Backer JA, Mesquita JR, Nascimento MS, Banks M, Martelli F, et al. Prevalence and transmission of hepatitis E virus in domestic swine populations in different European countries. BMC Res Notes. 2012;5:190.

http://dx.doi.org/10.1186/1756-0500-5-190 PMid:22534364 PMCid:PMC3479409

26. Bouwknegt M, Rutjes SA, Reusken CB, Stockhofe-Zurwieden $\mathrm{N}$, Frankena K, de Jong MC, et al. The course of hepatitis $E$ virus infection in pigs after contact-infection and intravenous inoculation. BMC Vet Res. 2009;5:7. http://dx.doi.org/10.1186/1746-6148-5-7 PMid:19193209 PMCid:PMC2647918

27. Bouwknegt M, Lodder-Verschoor F, van der Poel WH, Rutjes SA, de Roda Husman AM. Hepatitis E virus RNA in commercial porcine livers in The Netherlands. J Food Prot. 2007;70(12):2889-95. PMid: 18095450

28. Brassard J, Gagné MJ, Généreux M, Côté C. Detection of human food-borne and zoonotic viruses on irrigated, field-grown strawberries. Appl Environ Microbiol. 2012;78(10):3763-6. http://dx.doi.org/10.1128/AEM.00251-12 PMid:22427499 PMCid:PMC3346374 